\title{
BUILDING COMPETENCIES FOR SOCIAL WORK THROUGH CONTINUING VOCATIONAL TRAINING
}

\author{
Venelin Terziev ${ }^{1 *}$, Oleg Latyshev ${ }^{2}$, Marin Georgiev ${ }^{3}$ \\ ${ }^{1}$ Corresponding Member of the Russian Academy of Natural History, Moscow, Russia, Professor, \\ Ph.D., D.Sc. (National Security), D.Sc. (Ec.), University of Rousse, Rousse, Bulgaria; National \\ Military University, Veliko Tarnovo, Bulgaria; University of Telecommunications and Post, Sofia, \\ Bulgaria, terziev@skmat.com \\ ${ }^{2}$ Academician of the Russian Academy of Natural History, Moscow, Russia, Professor, Ph.D., \\ D.Sc., papa888@list.ru \\ ${ }^{3}$ National Military University, Veliko Tarnovo, Bulgaria, clementon@abv.bg \\ ${ }^{*}$ Corresponding author
}

\begin{abstract}
The occupation of the social worker in modern times is challenged by the dynamically changing economic and social environment, growing requirements to their qulifications and competences and the needs of gaining new skills and permanen development and improvement. The aim of the presented study of defining the needs for continuing vocational training of specialists providing social services is to provide recommendations regarding the need of training for skills contributing to the increase in the degree of correspondence between labor supply and demand on the labor market, contributing to the improvement of the quality of the labor force in the country as a competitive factor with an increasing importance for successful economic development. The investigation and the specific examples discussed can be a solid basis for future studies and development of models for improvement the system of continuing and vocational training for acquiring the needed knowledge, skills and competences for effective work.
\end{abstract}

Keywords: continuing training, vocational training, social worker, labor market.

\section{INTRODUCTION}

For two decades in Bulgaria now there has been conducted a reform in the field of vocational education and training provision in line with the changing needs of the labor market. Support has been provided by a number of programs and projects that assist a platform for continued reform aiming at turning strategic planning into a practical reality (Terziev, 2013).

The philosophy of labor market communication, understood in some countries in a slightly narrower sense as social dialogue, is at the heart of building the system of research, identification and monitoring of vocational training needs. The effectiveness of the functioning of a communication system depends exclusively on the political will and the political attitude of communication of all stakeholders. With the availability of appropriate legislation and qualified and motivated experts and employees in the institutions that play key roles in the system, the set of the above two attitudes will make a positive contribution to the 
country's development (Terziev, 2016, pp. 33-48; Terziev, Dimitrova, Arabska, 2015, pp. 70-79).

Labor market analysis in Bulgaria highlights significant communication deficits, both between individual public institutions and between institutions on the one hand, and employers and employees, on the other (Terziev, 2013) . Regarding the general situation on the labor market in Bulgaria and the state of vocational education and training, the representatives of the institutions of employment and social policy unanimously stress the need for radical changes in the cooperation between the labor market partners but also in the content of work, such as quality control of education and training services, collection and analysis of information on the needs of employers by qualified staff, accordance of education and training to employers' needs and others.

The systematic labor market communication requires equal and equally responsible participation of all labor market partners regardless of whether they are government structures or representatives of employers, employees, vocational training centers, regional and municipal administrations, non-governmental organizations and other. This way, each partner can get credible information if it has previously provided reliable information to other partners.

All studies that aim to make forecasts for skills and skill needs are characterized by some uncertainty about the expected results and expected effects. The introduction of a future-oriented labor market development system that includes skills needs analysis is a good step. But in reality it is not enough. Such a system can be useful only if it is part of a wider system. Broader systems provide information and professional communication among all stakeholders in the socio-economic sphere.

The expectation is that organizations in Bulgaria will increasingly focus in the future on the quality and improvement of the skills of their workforce (Terziev, V. 2009, pp. 389-392). The acute shortage of qualified workers and employees is also present in many of the economic sectors in the country, so the skills needs analyses will support the management and entrepreneurial decisions in the Bulgarian organizations. To achieve this, an organized mechanism should be set up to connect ministries, government agencies, social partners, employment services - private or government, chambers of commerce, vocational education and training institutions, employers 'organizations and employees' organizations. This organized mechanism should work by carrying out in sequence, in a certain order and without interruption, a series of research and analytical steps, as well as those related to the dissemination of information and the provision of continuous feedback.

The aim of the presented study of defining the needs for continuing vocational training of specialists providing social services is to increase the degree of correspondence between labor supply and demand on the labor market, contributing to the improvement of the quality of the labor force in the country as a competitive factor with an increasing importance for successful economic development.

In this sense, a realistic planning of human resources based on systematic monitoring and knowledge of the workforce must be achieved. The database collected must support the decision-making process in the areas of employment, labor market, vocational education and training, higher education, and the development of the workforce at national and regional level (Terziev, 2017a, pp. 55-78). In this context, the tasks of determining the needs for continuing vocational training of social work professionals are the following (Terziev; Terziev, Stanchev; Terziev, Arabska, 2016a, pp. 221-236; Terziev Arabska, 2016b, pp. 41-50; Terziev, Arabska, Filipov, Stanchev, 2016a, pp. 261-267; Terziev, Arabska, Filipov, Stanchev, 2016b, pp. 290-304; Terziev, Arabska, Filipov, Stanchev, 2016c, pp.268-276; Terziev, Arabska, Filipov, Stanchev, 2016d, pp. 277-289; Terziev, Arabska, 2016c, pp. 229-238, Terziev, Arabska, 2016d, pp. 198-205):

- Systematic analysis of the labor market;

- Systematic study and analysis of skills needs;

- Support the process of developing and permanently updating professional standards (in line with international standards) by providing systematic information for decision-making in this area;

- Support the process of developing and permanently updating educational standards by providing systematic information on decision-making in this field;

- Support the process of developing and permanently updating educational programs by providing systematic information on decision-making in this field;

- Development of curricula for vocational education and training (especially for adults);

- Development of training modules.

The study and determination of the need for continuing vocational training of social work professionals 
providing social services is seen as a process that goes from the labor market analysis, through the next steps to the development of curricula, programs and modules, and through the feedback again and continuously passes through the series of steps (Terziev, Arabska, 2016e, pp. 206-217; Terziev, Arabska, 2016f, pp. 218-228; Terziev, Stoyanov, 2016a, pp. 158-164; Terziev, Stoyanov, 2016b, pp. 136-142; Terziev, Stoyanov, 2016c, pp. 142-150).

The aim of the study of the needs of continuing vocational training in the Child Protection and Disability and Social Services Departments of the Social Assistance Directorates of the Social Assistance Agency in Bulgaria to improve the quality and effectiveness of social work is to define the needs of adequate training and measures to support social workers in order to achieve greater efficiency in social work in the context of lifelong learning and continuing vocational training. The aim of the study of the needs for continuing vocational training is also the identification of acceptable options for providing continuous training and upgrading adequate training of the employees to increase their qualification for working with different groups of clients. The main expected result of the analysis of the study is to ouline the basic needs for continuing vocational training for the employees of the two departments. For the sake of maximal accuracy, the survey is also aimed at examining the views of directors, heads of departments and chief experts in the Child Protection and Disability and Social Services Departments of the Social Assistance Directorates [22-45] (Terziev, Stoyanov, 2016d, pp. 225-234; Terziev, Bencheva, Stoeva, Arabska, 2016, pp. 63-74; Terziev, Bencheva, Arabska, 2016, pp. 55-63; Terziev, Bencheva, Tepavicharova, Arabska, 2016, pp. 45-55; Terziev, Arabska, 2016g, pp. 391-400; Terziev, Arabska, 2016h, pp. 409-416; Terziev, Arabska, 2016i, pp. 401-408; Terziev, 2016c, pp. 23-64; Terziev, Dimitrova, 2014a, pp. 281-293; Terziev, Dimitrova, 2014b, pp. 294-207; Terziev, Arabska, 2016j, pp.19-24; Terziev, 2016d, pp. 47-63; Terziev, Stoyanov, Arabska, 2016; Dimitrovski, Terziev, Saliu, Pushova, 2016, pp. 879-884; Terziev. V,; Terziev, Arabska, Dimitrovski, Pushova, 2016; Terziev, 2016e, pp. 11-18, Terziev, Arabska, 2016k, pp. 51-60; Terziev, 2016f, pp. 100-113, Terziev. 2017a, pp. 928-935, Terziev, Arabska, 2017a, pp. 1151-1159; Terziev, Nichev, Simeonov pp. 1321-1338; Terziev, Arabska, 2017b, pp. 1339-1355).

\section{MATERIAL AND METHODS}

The research tools in studing the needs of continuing vocational training in the Child Protection and Disability and Social Services Departments of the Social Assistance Directorates of the Social Assistance Agency for improving the quality and effectiveness of social work use information by the following sources:

- Specialized questionnaires for employees in the Child Protection and Disability and Social Services Departments of the Social Assistance Directorates.

- Specialized questionnaires for directors of directorates, heads of departments and chief experts in the Child Protection and Disability and Social Services Departments of the Social Assistance Directorates.

Questionnaires are a tool for achieving three major goals:

1.Gathering information on the specific training and qualification needs of employees;

2.Identification and prioritization of specific training needs and topics;

3.Defining the target groups, types and forms of training that employees of Child Protection and People with Disabilities and Social Services need in the Social Assistance Directorates and directors of directorates, heads of department and chief experts in Child Protection and People with Disabilities and Social Services Divisions at the Social Assistance Directorates.

The target group is generally defined - employees of the Child Protection and Disability and Social Services Departments of the Social Assistance Directorates, the interviewing of which will enable the process of identifying the needs for continuing vocational training to be completed.

For the purposes of the study of the needs of continuing vocational training in the Departments Child Protection and People with Disabilities and Social Services an instruction is developed for carrying out the research, which shows the steps and important moments in the immediate gathering of information by completing the questionnaires. The instruction contains the basic requirements and is a reference in the process of collecting information such as:

- How the survey is presented, what are its objectives, the person who realizes it;

- How to identify the employees to be surveyed;

- Requirements for strictness of information, accuracy of filling;

- Special issues and requirements for them; 
- Deadline for submitting filled-in questionnaires and exact sending address.

For each of the target groups (employees of the Child Protection and Disability and Social Services Departments of the Social Assistance Directorates and directors of directorates, heads of department and chief experts in Child Protection Departments and People with Disabilities and Social Services), individual questionnaires were developed. The questionnaire for employees of the Child Protection and Disability and Social Services Departments of the Social Assistance Directorates is anonymous in order to obtain reliable information.

In the questionnaire for the employees of the Departments of Child Protection and People with Disabilities and Social Services in the Social Assistance Directorates the issues are divided into three sections:

Section I. General profile of surveyed employees - includes issues related to gender, age, completed final education, completed final qualification, current job position and social work experience. Questions are common to both departments.

Section II. The level of competence of experts and social workers is divided into two parts common to both departments.

Part A. Knowledge of social work of the interviewed employees - questions are included to determine whether the acquired knowledge about social work (formal and informal) helps social workers to carry out activities such as informing, actively listening, assessing the needs of the clients, maintaining positive work Customer relations, preparation of individual plans for working with clients, planning and managing the intervention, setting priorities in the work.

Part B. Social Work Skills for Responding Employees - Are issues to determine the social work skills acquired by social workers, such as taking into account different points of view in collecting information, establishing effective contact with people, planning the actions to achieve the Purpose, creating working relationships, maintaining positive working relationships, applying the ethical principles of social work, recognizing risk situations, analyzing risk and potential time For both yourself and others, job satisfaction.

Section III. Need for training and career development of respondents. The section includes different questions for the two departments, with the aim of maximizing accuracy in determining the need for adequate training, such as introductory trainings, types of trainings, upgrading trainings, time and place, duration, professional and career development, different areas needed super vision.

The purpose of the questionnaire for directors of directorates, heads of unit and chief experts in the Child Protection and Disability and Social Services Departments of the Social Assistance Directorates is to determine the level of competence of employees in the Protection Departments Child and Disabled and Social Services through "managers' eyes". It contains two sections:

Section I. Direct supervisor interview - includes issues related to the review of the overall operational work, such as daily tasks, responsibilities, job requirements, effective communication with clients and colleagues, degree of satisfaction, signs of insufficient motivation of the teams.

Section II. Level of competencies of the employees in the Child Protection and Disability and Social Services Departments in the Social Assistance Directorates assessed by the managers - these include issues to determine attitudes towards positive communication in the work with clients, skills Teamwork and experience sharing, work with documentation on social services, skills for working with difficult or disadvantaged clients, attitudes to self-assessment of own qualities and deficits, the need for additional vocational training and super vision by species.

The processing of information gathered from questionnaires is conducted through the following procedural steps:

- Preparing a matrix of entering information.

- Introduction of the information or the conversion of the information collected in numerical order, which is suitable subsequently for quantitative processing; entering the numeric values that correspond to each of the options provided in the questionnaire; Depending on the type of question for each variable, a different number of responses and their corresponding numeric expressions are possible.

- Statictical processing - in this case are suitable one-dimensional and two-dimensional distributions, medium arithmetic, median and mode, tests for static significance and hypothesis testing.

\section{RESULTS AND DISCUSSION}

The questionnaire intended for employees of the Child Protection Departments was organized to fill in a 
paper format of 23 pages. 767 respondents completed and returned it, with 468 respondents answering all questionnaires.

The questionnaire contained a total of 76 questions divided by sections. 11 are the questions requiring general information, 62 have the choice of just one answer, 3 with the choice of more than one answer, 2 are open questions and 1 question of prioritizing and mentioning more than one answer.

Regarding the distribution of the respondents by sex the share of social workers - women is the highest $90,6 \%$ of the total number.

$48,5 \%$ of respondents are aged $36-55$ years, $33,8 \%$ are $26-35$ years old and only $12,1 \%$ up to 25 years. (Table 1).

On the question of the type of completed education, $85,9 \%$ answered higher education, of which $51,0 \%$ hold a Master's degree and $34,9 \%$ have a Bachelor's degree. Secondary education workers account for a total of $13,8 \%$ (Table 2).

Interesting information provides the question "Year of completion of the last education". As can be seen from Table 4, the number of graduates has increased since $1995-2,2 \%, 2000-5,4 \%, 2005-5,9 \%, 2011-$ $8,2 \%$ compared to $1972-0,4 \%, 1977-0,5 \%, 1982-0,7 \%, 1990-0,8 \%$.

Interesting information provides the question "Year of completion of the last education". The number of graduates has increased since $1995-2,2 \%, 2000-5,4 \%, 2005-5,9 \%, 2011-8,2 \%$ compared to $1972-$ $0,4 \%, 1977-0,5 \%, 1982-0,7 \%, 1990-0,8 \%$.

Of all the employees, $36.9 \%$ graduated from the professional field "Social activities", while 63,1\% specialties from other professional fields. (Table 3).

On the question about last qualification $49,3 \%$ of the respondents indicated a key competence / certification course and $41,9 \%$ - professional qualification. The percentage of respondents to this question is $43,9 \%$ (Table 4).

Table 1. Age characteristics of participants in the survey

\begin{tabular}{|l|c|c|c|c|}
\hline \multicolumn{1}{|c|}{ Age } & Frequenscy & Percent & Valid Percent & $\begin{array}{c}\text { Cumulative } \\
\text { Percent }\end{array}$ \\
\hline up to 25 & 93 & 12,1 & 12,2 & 12,2 \\
\hline $26-35$ & 259 & 33,8 & 33,9 & 46,1 \\
\hline $36-55$ & 372 & 48,5 & 48,7 & 94,8 \\
\hline over 56 & 40 & 5,2 & 5,2 & 100,0 \\
\hline with response & 764 & 99,6 & 100,0 & \\
\hline without response & 3 & 0,4 & & \\
\hline total & 767 & 100,0 & & \\
\hline
\end{tabular}

Table 2. Educational characteristics of participants in the survey

\begin{tabular}{|l|c|c|c|c|}
\hline \multicolumn{1}{|c|}{ Last education } & Frequenscy & Percent & Valid Percent & $\begin{array}{c}\text { Cumulative } \\
\text { Percent }\end{array}$ \\
\hline Higher & 40 & 5,2 & 5,2 & 5,2 \\
\hline Vocational & 66 & 8,6 & 8,6 & 13,9 \\
\hline Bachelor & 268 & 34,9 & 35,0 & 48,9 \\
\hline
\end{tabular}


IJAEDU- International E-Journal of Advances in Education, Vol. III, Issue 9, December 2017

\begin{tabular}{|l|c|c|c|c|}
\hline Master & 391 & 51,0 & 51,1 & 100,0 \\
\hline With response & 765 & 99,7 & 100,0 & \\
\hline Without response & 2 &, 3 & & \\
\hline Total & 767 & 100,0 & & \\
\hline
\end{tabular}

Table 3. Information about the professional fields and specialties

\begin{tabular}{|l|c|c|c|c|}
\hline Professional field of education & Frequenscy & Percent & Valid Percent & Cumulative Percent \\
\hline Social activities & 216 & 28,2 & 36,9 & 36,9 \\
\hline Other & 370 & 48,2 & 63,1 & 100,0 \\
\hline With response & 586 & 76,4 & 100,0 & \\
\hline Without response & 181 & 23,6 & & \\
\hline Total & 767 & 100,0 & & \\
\hline
\end{tabular}

Table 4. Information on the last acquired qualification

\begin{tabular}{|l|c|c|c|c|}
\hline \multicolumn{1}{|c|}{ Last qualification } & Frequenscy & Percent & Valid Percent & Cumulative Percent \\
\hline Post-graduate specialization & 37 & 4,8 & 8,6 & 8,6 \\
\hline Vocational qualification & 180 & 23,5 & 41,9 & 50,5 \\
\hline Key competence, certified course & 212 & 27,6 & 49,3 & 99,8 \\
\hline With response & 430 & 56,1 & 100,0 & \\
\hline Without response & 337 & 43,9 & & \\
\hline Total & 767 & 100,0 & & \\
\hline
\end{tabular}

Table 5. Distribution of interviewees by length of service

\begin{tabular}{|l|c|c|c|c|}
\hline \multicolumn{1}{|c|}{ Service in the social sphere } & Frequenscy & Percent & Valid Percent & Cumulative Percent \\
\hline Up to 2 years & 320 & 41,7 & 42,4 & 42,4 \\
\hline 2-10 years & 243 & 31,7 & 32,2 & 74,7 \\
\hline 11-20 years & 156 & 20,3 & 20,7 & 95,4 \\
\hline Over 20 years & 35 & 4,6 & 4,6 & 100,0 \\
\hline With response & 754 & 98,3 & 100,0 & \\
\hline Without response & 13 & 1,7 & & \\
\hline Total & 767 & 100,0 & & \\
\hline
\end{tabular}

The distribution of interviewed employees by internship in the social sphere is presented in Table 5, which 
shows that the highest percentage of $42,4 \%$ is for employees with a work experience of up to 2 years and only $4,6 \%$ for those with experience over 20 years. $1,7 \%$ of respondents did not respond.

The question "Before you start working on a specific case you get to know the information available" 694 respondents answered „always detailed“, which accounts for $91 \%$. A negative "always missing information" response was 2,2\%. Four did not respond.

To obtain additional information that can be useful in establishing initial contact, $53,7 \%$ of respondents have indicated "always" and 39,3\% - "connect if necessary" - an indicative result for good teamwork and quality work.

To the question „Evaluate all available information to determine the best form to establish primary contact" $83,6 \%$ of social workers responded "always in detail“ and only $4,9 \%$ said "do not make judgments, go to work".

Informing the clients about their rights, opportunities and responsibilities is done according to $93,4 \%$ "always, in detail", $4,7 \%$ have indicated "always but in part", „I inform them when they ask me" $-1,7 \%$ of respondents, and $0,1 \%$ does not inform them. Five employees did not answer the question.

Explanations of the duties and responsibilities of the social workers, as well as those of the unit in which they work, are „always, in detail“ - 72,8\%, „always but in part“ $-17,9 \%$, „Explain when asked“ $-8,5 \%$ and „Do not explain“ - only $0,8 \%$ of the respondents.

In the questions of indicating the client's help to understand the information related to the case, to express expectations, to make an informed decision $85,5 \%$ of the respondents answered „always, in detail“, „do not help“ have indicated only $0,5 \%$ of respondents.

On the question "Are you actively listening to your customers" 95,9\% answered "always with details", "always, but in part" - 4,1\%. Two employees did not respond, and the answers "do not listen because I do not care" and "do not listen because I do not have enough time" were not mentioned.

When assessing the needs of the clients $88,1 \%$ of the social workers take into account their specificities, the existing risks and opportunities as „always, in detail“. $6,9 \%$ of respondents consider „always, but in part", $2,9 \%$ comply with normative documents only and only $2,1 \%$ said "I can not take everything". Two of the social workers did not answer.

Despite the busy workday $78,4 \%$ of the social workers maintain a positive working relationship with the client „always" and $20,2 \%$ answererd that "not always, it depends on the client". A positive attitude of mood for the day was determined by $1,1 \%$ of social workers, and two employees never support this attitude. The results are presented in Table. 6 .

The preparation of individual customer service plans is "always" performed by $72,8 \%$ of the surveyed social workers. Response "always, not very detailed“ indicated $15,3 \%$ of the respondents, and $8,8 \%$ of them - „I always borrow from others like this". Only $2,3 \%$ did not produce individual plans, and 16 employees did not answer this question. The results are presented in Table 7.

Collaboration with colleagues and other professionals at work is supported by $98,7 \%$ of respondents, and only $1,3 \%$ of them have mistrust their colleagues' competence and have marked a "do not discuss because they are not so competent".

Table 6. Status of work relationships

\begin{tabular}{|l|c|c|c|c|}
\hline $\begin{array}{l}\text { You are able to maintain a positive } \\
\text { working relationship with the client }\end{array}$ & Frequenscy & Percent & Valid Percent & $\begin{array}{c}\text { Cumulative } \\
\text { Percent }\end{array}$ \\
\hline always & 597 & 77,8 & 78,4 & 78,4 \\
\hline $\begin{array}{l}\text { Not always, it depends on my mood } \\
\text { for the day }\end{array}$ & 8 & 1,0 & 1,1 & 79,5 \\
\hline Not always, it depends on the client & 154 & 20,1 & 20,2 & 99,7 \\
\hline Never & 2 & 0,3 & 0,3 & 100,0 \\
\hline With response & 761 & 99,2 & 100,0 & \\
\hline
\end{tabular}


IJAEDU- International E-Journal of Advances in Education, Vol. III, Issue 9, December 2017

\begin{tabular}{|l|c|c|c|l|}
\hline Without response & 6 &, 8 & & \\
\hline Total & 767 & 100,0 & & \\
\hline
\end{tabular}

Table 7. Individual plans for work with clients

\begin{tabular}{|l|c|c|c|c|}
\hline $\begin{array}{c}\text { You prepare individual client service } \\
\text { plans }\end{array}$ & Frequenscy & Percent & Valid Percent & $\begin{array}{c}\text { Cumulative } \\
\text { Percent }\end{array}$ \\
\hline Always, detailed & 547 & 71,3 & 72,8 & 72,8 \\
\hline Always, not very detailed & 115 & 15,0 & 15,3 & 88,1 \\
\hline Always, borrowing from others like it & 66 & 8,6 & 8,8 & 96,9 \\
\hline I do not & 22 & 2,9 & 2,9 & 99,9 \\
\hline No & 1 & 0,1 & 0,1 & 100,0 \\
\hline With response & 751 & 97,9 & 100,0 & \\
\hline Without response & 16 & 2,1 & & \\
\hline Total & 767 & 100,0 & & \\
\hline
\end{tabular}

With behavior that represents a risk in the work of a social worker $40,1 \%$ of respondents do not have difficulties, and $48,7 \%$ of them face „not very serious difficulties“. Serious difficulties are experienced by $9,5 \%$ of the employees, with very serious difficulties and unable to cope with - $1,8 \%$.

The question "You are able to plan and manage the intervention in a way that will positively change the recognized risk behavior" $84,3 \%$ of the respondents are dealing without difficulty and with not very serious difficulties. Serious difficulties in planning and managing intervention were mentioned by $14,3 \%$, and $1,4 \%$ of social workers are unable to cope.

Planning and taking immediate action to meet the urgent needs and requirements of the client is done "always, on a daily basis" by $66,5 \%$ of the employees of the department and "always but not daily" by $27,4 \%$. Only $5,6 \%$ of respondents said "not always because they are already large" and $0,5 \%$ "because I do not have enough time".

To the question "Do you follow the changes in the normative documents related to your work" were given prevailing positive answers with $46,1 \%$ being informed once a week and $37,7 \%$ once a month. The remaining $13,0 \%$ rely on managers to inform, and $3,3 \%$ relied on colleagues' competence. Three employees have not listed any of the suggested answers.

$50,7 \%$ of respondents in the department deal with ethical dilemmas and conflicts at work and manage their workload because they have the knowledge, techniques and experience to do so. Serious difficulties, however, are experienced by $44,4 \%$ of social workers and only $0,8 \%$ can not cope because they have no knowledge and techniques to do so. Five staff members did not respond.

The question of whether the job requires continual improvement of qualification was given answers by $56,0 \%$ with "once every 6 months". 36,1\% said "once a year". 6,4\% said there was no need to improve the qualification, „because there are not many changes“, and „it is superfluous" have indicated $1,5 \%$. Fourteen of the study participants did not respond to the question presented in Table 8.

Professional contacts with colleagues inside and outside the organization are supported by $95,8 \%$ of department employees, $37,8 \%$ of them doing daily, and the remaining $58,0 \%$ not constantly. $3,5 \%$ of respondents rely on managers to guide their work, and $0,7 \%$ said they did not maintain such contacts „because it is superfluous" and „because there is no time“. Only five employees did not answer this question.

The open question of what are the reasons for the difficulties in implementing the activities in social work as a whole were given answers covering problems of 20 areas. Firstly, $20,2 \%$ of respondents indicated lack of equipment and supplies at work. Secondly, by 9,6\% high workload and a large volume of work cases were 
highlighted. Third, $7,0 \%$ reported the lack of adequate facilities and poor working conditions. Fourth, 5,1\% pointed the lack of consumer support. Fifth place with $4,4 \%$ is the lack of organized transport and remoteness in the workplace to the clients. Interesting is the fact that all 767 social workers from the Child Protection Departments have answered this question.

Table 8. Requirements for improvement of qualification

\begin{tabular}{|l|c|c|c|c|}
\hline $\begin{array}{c}\text { Your job requires constantly improving } \\
\text { your qualification }\end{array}$ & Frequenscy & Percent & Valid Percent & $\begin{array}{c}\text { Cumulative } \\
\text { Percent }\end{array}$ \\
\hline Yes, once every 6 months & 422 & 55,0 & 56,0 & 56,0 \\
\hline Yes, but once a year & 272 & 35,5 & 36,1 & 92,2 \\
\hline $\begin{array}{l}\text { No, because there are not many } \\
\text { changes }\end{array}$ & 48 & 6,3 & 6,4 & 98,5 \\
\hline No, because it is superfluous & 11 & 1,4 & 1,5 & 100,0 \\
\hline With response & 753 & 98,2 & 100,0 & \\
\hline Without response & 14 & 1,8 & & \\
\hline Total & 767 & 100,0 & & \\
\hline
\end{tabular}

Regarding the acquirement of professional duties and their fulfillmentwithout problems $42,2 \%$ of the respondents reported „over 4 weeks" and 22,9\% „up to 4 weeks“. 16,0\% still have a performance problem. 19 employees could not judge and answer this question. The data are presented in Table 9.

On the question „Do you e make a difference between various theories, policies, procedures and methods of intervention", $757 \%$ of respondents in the departments do not encounter any difficulties, while $20,9 \%$ deal but have serious difficulties. 3,3\% employees can not handle and rely on help from colleagues. Seven social workers did not responded to this question, as evidenced by Table 10.

Table 9. Acquiring professional skills when starting work

\begin{tabular}{|l|c|c|c|c|}
\hline $\begin{array}{c}\text { When you started work, how long did it take to } \\
\text { get your job done and run it smoothly }\end{array}$ & Frequenscy & Percent & Valid Percent & $\begin{array}{c}\text { Cumulative } \\
\text { Percent }\end{array}$ \\
\hline 1 week & 27 & 3,5 & 3,6 & 3,6 \\
\hline Up to 2 weeks & 48 & 6,3 & 6,4 & 10,0 \\
\hline Up to 3 weeks & 66 & 8,6 & 8,8 & 18,9 \\
\hline Up to 4 weeks & 171 & 22,3 & 22,9 & 41,7 \\
\hline Over 4 weeks & 316 & 41,2 & 42,2 & 84,0 \\
\hline I still have a performance problem & 120 & 15,6 & 16,0 & 100,0 \\
\hline With response & 748 & 97,5 & 100,0 & \\
\hline Without response & 19 & 2,5 & & \\
\hline Total & 767 & 100,0 & & \\
\hline
\end{tabular}


Table 10. Knowledge on different theories, policies, procedures and methods of intervention

\begin{tabular}{|l|c|c|c|c|}
\hline $\begin{array}{c}\text { Do you e make a difference between various } \\
\text { theories, policies, procedures and methods of } \\
\text { intervention? }\end{array}$ & Frequenscy & Percent & Valid Percent & $\begin{array}{c}\text { Cumulative } \\
\text { Percent }\end{array}$ \\
\hline Yes, I do not have difficulty & 575 & 75,0 & 75,7 & 75,7 \\
\hline Yes, but I have serious difficulties & 159 & 20,7 & 20,9 & 96,6 \\
\hline $\begin{array}{l}\text { I can not cope because I have extremely } \\
\text { serious difficulties }\end{array}$ & 1 & 0,1 & 0,1 & 96,7 \\
\hline I can not cope, I rely on help from colleagues & 25 & 3,3 & 3,3 & 100,0 \\
\hline With response & 760 & 99,1 & 100,0 & \\
\hline Without response & 7 & 0,9 & & \\
\hline Total & 767 & 100,0 & & \\
\hline
\end{tabular}

When working with people in different problematic situations $89,0 \%$ of the employees are using an analysis of the consequences of social inequality, discrimination and social exclusion. Serious difficulties were marked by $9,3 \%$. On help from colleagues rely $1,4 \%$ of surveyed social workers. Only three employees of the Child Protection Department did not answer this question. The information is presented in Table 11.

Table 11. Analyzing the implications of social inequality

\begin{tabular}{|l|c|c|c|c|}
\hline $\begin{array}{c}\text { When working with people in different } \\
\text { problematic situations, can you analyze the } \\
\text { consequences of social inequality, } \\
\text { discrimination and social exclusion? }\end{array}$ & Frequenscy & Percent & Valid Percent & $\begin{array}{c}\text { Cumulative } \\
\text { Percent }\end{array}$ \\
\hline Yes, I do not have difficulty & 680 & 88,7 & 89,0 & 89,0 \\
\hline Yes, but I have serious difficulties & 71 & 9,3 & 9,3 & 98,3 \\
\hline I can not cope because I have extremely \\
serious difficulties
\end{tabular}

Table 12. Prejudices to clients

\begin{tabular}{|l|c|c|c|c|}
\hline $\begin{array}{c}\text { Do you overcome your prejudices to your } \\
\text { clients in social work? }\end{array}$ & Frequenscy & Percent & Valid Percent & $\begin{array}{c}\text { Cumulative } \\
\text { Percent }\end{array}$ \\
\hline Yes, I always try & 720 & 93,9 & 94,4 & 94,4 \\
\hline Not always, it depends on my mood for the day & 14 & 1,8 & 1,8 & 96,2 \\
\hline Not always, it depends on colleagues, the client & 15 & 2,0 & 2,0 & 98,2 \\
\hline
\end{tabular}


IJAEDU- International E-Journal of Advances in Education, Vol. III, Issue 9, December 2017

\begin{tabular}{|l|c|c|c|c|}
\hline I can not assess & 14 & 1,8 & 1,8 & 100,0 \\
\hline With response & 763 & 99,5 & 100,0 & \\
\hline Without response & 4 & 0,5 & & \\
\hline Total & 767 & 100,0 & & \\
\hline
\end{tabular}

Table 13. Satisfaction with work

\begin{tabular}{|l|c|c|c|c|}
\hline \multicolumn{1}{|c|}{ Are you satisfied with your work? } & Frequenscy & Percent & Valid Percent & $\begin{array}{c}\text { Cumulative } \\
\text { Percent }\end{array}$ \\
\hline Yes & 316 & 41,2 & 41,3 & 41,3 \\
\hline Partly & 415 & 54,1 & 54,2 & 95,6 \\
\hline No & 34 & 4,4 & 4,4 & 100,0 \\
\hline With response & 765 & 99,7 & 100,0 & \\
\hline Without response & 2 &, 3 & & \\
\hline Total & 767 & 100,0 & & \\
\hline
\end{tabular}

Table 14. Expectations from the profession of social worker

\begin{tabular}{|l|c|c|c|c|}
\hline $\begin{array}{c}\text { Have your expectations for the social worker } \\
\text { profession been met? }\end{array}$ & Frequenscy & Percent & Valid Percent & $\begin{array}{c}\text { Cumulative } \\
\text { Percent }\end{array}$ \\
\hline Yes & 240 & 31,3 & 31,8 & 31,8 \\
\hline Partly & 432 & 56,3 & 57,3 & 89,1 \\
\hline No & 82 & 10,7 & 10,9 & 100,0 \\
\hline With response & 754 & 98,3 & 100,0 & \\
\hline Without response & 13 & 1,7 & & \\
\hline Total & 767 & 100,0 & & \\
\hline
\end{tabular}

Table 15. Opportunities to work in another professional sphere

\begin{tabular}{|l|c|c|c|c|}
\hline $\begin{array}{c}\text { If you are given the opportunity to work in } \\
\text { another sphere, would you leave the social } \\
\text { one? }\end{array}$ & Frequenscy & Percent & Valid Percent & $\begin{array}{c}\text { Cumulative } \\
\text { Percent }\end{array}$ \\
\hline Definitely yes & 140 & 18,3 & 18,6 & 18,6 \\
\hline I hesitate & 430 & 56,1 & 57,0 & 75,6 \\
\hline Definitely no & 184 & 24,0 & 24,4 & 100,0 \\
\hline With response & 754 & 98,3 & 100,0 & \\
\hline Without response & 13 & 1,7 & & \\
\hline
\end{tabular}


Considering overcoming the prejudices to the clients in the social work $94,4 \%$ of the employees in the departments deal. Depending on other factors such as momentary mood, colleagues, the client $5,6 \%$ of the respondents work. Only four employees did not answer the question (Table 12).

Only $41,3 \%$ of social workers are satisfied with their work, and $54,1 \%$ in part account for this. Unsatisfied are $4,4 \%$ of department employees. Two employees did not answer (Table 13).

It is interesting that the expectations for the profession of social worker have fully justified by $31,8 \%$ of the employees of the Child Protection Departments, in part $-57,3 \%$, while the answer "no" was indicated by 10,9\% of the respondents. Thirteen employees did not respond, as evidenced by Table. 14.

To the question "If you are given the opportunity to work in another sphere, would you leave the social one“ the answer "Definetly yes" was given by $18,6 \%$. The hesitation is $57,0 \%$, and „definitely not" was mentioned by $24,4 \%$ of the surveyed social workers. Thirteen did not answer the question. The data are presented in Table 15.

When answering the question "When starting in the department did you receive an introductory training" $46,5 \%$ of the employees in the departments responded categorically "yes“. $23,1 \%$ have received introductory training ",in part" and 30,4\% have not been introduced through training at work. Eight social workers did not answer this question.

$29,9 \%$ of social workers were involved in trainings organized by the agency, $24,8 \%$ - in part, and $45,3 \%$ were not involved in training. $1,8 \%$ of respondents did not want to answer.

On the question of what kind of trainings as an organizational form the employees of the Child Protection Departments need, with the possibility to indicate a combination of several types, $43,6 \%$ of the respondents pointed to the necessity of specialized training with practical orientation, $28,4 \%$ of them prefer participating in a dedicated forum to transfer good practices. $14,3 \%$ defined their need for a narrow specialized talk, seminar, and 7,0\% prefer distance learning. All respondents answered this question as $59,4 \%$ of the social workers in the departments gave more than one answer.

On the question about the time for the trainings in which the respondents would be involved $52,1 \%$ said that it should be done at work and with almost equal percentages $16,0 \%$ and $16,5 \%$ were employees who prefer training to take place after working hours of up to 2 hours, or during the the weekends for one day. $8,8 \%$ of respondents are willing to spend several days of paid annual leave to take part in upgrading training, and $6,6 \%$ of the surveyed social workers were for both days in the weekends.

On the question of the place of the trainings in which respondents would take place $47,0 \%$ of the surveyed employees prefer trainings held in the same location where they work. $30,4 \%$ tend to travel and join training in another location, and $22,7 \%$ prefer workplace training. $80,1 \%$ of the respondents gave one answer and the other $19,9 \%$ gave two answers.

On the question of the optimal duration of the training that the respondents would participate $48,1 \%$ indicated that it should be within 3 days, and $29,4 \%$ said they could spend up to 10 days (in modules) to participate in training to improve their professional qualification. Only $14,9 \%$ said they would have the opportunity to participate in training that lasts up to 1 day. For longer (more than 1 month) module training $7,7 \%$ of employees in the departments were identified.

To the question of what to emphasize in the organization of the upgrading trainings answers were given to all proposed in the survey. First of all, 50,5\% of the respondents have indicated that the lecturers should be qualified and competent, well prepared, familiar with the problems of social workers and offering quality training. Secondly, $28,8 \%$ focused on the choice of detailed materials to be used during and after the training. Next, $15,2 \%$ of employees rely on training, organized and provided with the agency's resources, and $5,4 \%$ of respondents prefer trainings to be run by university lecturers.

On the question of what would help for career and career development of social workers, respondents answered as follows:

- Participation in specialized training - a positive answer by $29,7 \%$;

- Sharing good practice $-29,2 \%$ gave a positive response;

- Exchange of information with other colleagues in the country $-13,6 \%$ answered this question; 
- Obtaining specialized literature $-11,7 \%$ of the respondents gave an affirmative answer;

- Providing an expert solution to a problem - $11,7 \%$ of respondents gave a response that is of great importance to social workers;

- Access to models of internal administrative documents - 4,1\% have given a positive answer.

In 15 different areas respondents answered to the question of areas of their work in which social workers are in need of additional training (Table 16).

Table 16. Topics of additional training

\begin{tabular}{|c|l|c|}
\hline № & \multicolumn{1}{|c|}{ Topic of additional training } & Percent \\
\hline 1 & Competencies and skills to work in critical situations, stress and stress & $22,20 \%$ \\
\hline 2 & Competence in direct work with clients & $10,80 \%$ \\
\hline 3 & Competence for carrying out social diagnostics & $8,40 \%$ \\
\hline 4 & Analyzing skills, social forecasting and planning & $8,30 \%$ \\
\hline 5 & Competence to take decisions & $7,60 \%$ \\
\hline 6 & Competence to identify needs and opportunities & $7,40 \%$ \\
\hline 7 & Competence and skills for individual and team work & $6,40 \%$ \\
\hline 8 & Cognitive competence & $5,60 \%$ \\
\hline 9 & General competence - personal and behavioral skills and characteristics & $5,20 \%$ \\
\hline 10 & Administrative competence & $5,10 \%$ \\
\hline 11 & Technical skills and competences & $3,40 \%$ \\
\hline 12 & Managerial competencies & $2,70 \%$ \\
\hline 13 & Organizational competence & $2,60 \%$ \\
\hline 14 & Communicative competence & $2,20 \%$ \\
\hline 15 & Entrepreneurial competence & $2,20 \%$ \\
\hline
\end{tabular}

In the first place, $22,2 \%$ of all respondents, regardless of their professional experience, responded that special training on "Competencies and skills to work in critical situations, tensions and stress" should be organized. This gives the reason to assert that social work is extremely psychological and stressful. This is confirmed by the answers to the next question to which $10,8 \%$ responded that they would engage in training on "Competence in direct work with clients". The social worker looks for opportunities to acquire new knowledge, skills and techniques for dealing with consumers. Thirdly, $8,4 \%$ of respondents indicated training on "Competence to perform social diagnostics". The third place with $8,3 \%$ is for the identified training on "Skills for analyzing, social forecasting and planning" due to the close result that the respondents have indicated. Fourth, 7,6\% of the respondents reported training on "Competence for decision-making".

On the question of prioritizing the main themes of introductory training for new social workers, respondents were asked to indicate one or a combination of several of the following preformulated topics:

- Social policy and legal framework in the field of child protection;

- Team management, teamwork and communications in social work;

- Organizational behavior in social work; 
- Social work with children and families at risk;

- Organization and specificity of the activities carried out in the department;

- The process of deinstitutionalization - social policies;

- Fundamentals and methods in the work of the social worker.

The most important thing is the topic of social work with children and families at risk with $69,0 \%$. Secondly, $35,6 \%$ of the votes included the topic Social policy and the legal framework in the field of child protection, and thirdly $31,5 \%$ the topic of fundamentals and methods in the work of the social worker in the social welfare sector. As the most insignificant topic at the time of the survey, $13.3 \%$ of respondents indicated the training in organizational behavior in the social work. The prioritization of all proposed topics for further training is presented in Table 17. Social workers have given more than one answer, so the number of answers is larger than the number of respondents.

Respondents from the Child Protection Departments were asked to identify their preference for participating in upgrading trainings. Sixteen of the the topics were predefined, and the respondents could indicate one answer or a combination of several. The following results were obtained, the responses being ranked downwards according to the percentage of positive responses as shown in Table 18.

Table 17. Topics of introductory training

\begin{tabular}{|l|c|c|c|}
\hline \multirow{2}{*}{ Topics for introductory training for newly recruited social workers } & \multicolumn{2}{|c|}{ Answers } & \multirow{2}{*}{$\begin{array}{c}\text { Cumulative } \\
\text { percent }\end{array}$} \\
Social work with children and families at risk & Number & Percent & \\
\hline Social policy and legal framework in the field of child protection & 171 & $16,00 \%$ & $35,60 \%$ \\
\hline Fundamentals and methods in the social worker's work & 151 & $14,10 \%$ & $31,50 \%$ \\
\hline The process of deinstitutionalization - social policies & 136 & $12,70 \%$ & $28,30 \%$ \\
\hline Organization and specificity of the activities carried out in the & 119 & $11,10 \%$ & $24,80 \%$ \\
\hline department & 98 & $9,20 \%$ & $20,40 \%$ \\
\hline Team management, teamwork and communications in social work & 64 & $6,00 \%$ & $13,30 \%$ \\
\hline Organizational behavior in social work & 1070 & $100,0 \%$ & $222,9 \%$ \\
\hline Total & $980 \%$ & \\
\hline
\end{tabular}

Table 18. Topics of advanced training

\begin{tabular}{|l|c|c|c|}
\hline \multirow{2}{*}{ Topics for advanced training of social workers from Child Protection } & \multicolumn{2}{|c|}{ Answers } & \multirow{2}{*}{$\begin{array}{c}\text { Cumulative } \\
\text { percent }\end{array}$} \\
\cline { 2 - 3 } & Number & Percent & \\
\hline $\begin{array}{l}\text { Methods of working with children - victims of violence and their } \\
\text { families }\end{array}$ & 370 & $13,10 \%$ & $55,10 \%$ \\
\hline Methods to manage the case of a child at risk & 255 & $9,00 \%$ & $38,00 \%$ \\
\hline $\begin{array}{l}\text { Methods for early diagnosis of the risk of child abandonment and } \\
\text { prevention of abandonment }\end{array}$ & 253 & $8,90 \%$ & $37,70 \%$ \\
\hline $\begin{array}{l}\text { Foster care - an alternative form for raising children in a family } \\
\text { environment - process and specific features }\end{array}$ & 244 & $8,60 \%$ & $36,40 \%$ \\
\hline
\end{tabular}


IJAEDU- International E-Journal of Advances in Education, Vol. III, Issue 9, December 2017

\begin{tabular}{|l|c|c|c|}
\hline Working with children - victims of trafficking and their families & 231 & $8,20 \%$ & $34,40 \%$ \\
\hline Family counseling & 214 & $7,60 \%$ & $31,90 \%$ \\
\hline Child reintegration - a process of specific features & 193 & $6,80 \%$ & $28,80 \%$ \\
\hline Deinstitutionalization - effect on child development & 172 & $6,10 \%$ & $25,60 \%$ \\
\hline Current issues of social work & 171 & $6,00 \%$ & $25,50 \%$ \\
\hline Current problems and specifics in the adoption of children & 162 & $5,70 \%$ & $24,10 \%$ \\
\hline Early intervention & 118 & $4,20 \%$ & $17,60 \%$ \\
\hline Family group conference - application possibilities & 105 & $3,70 \%$ & $15,60 \%$ \\
\hline Organization of resident type social services & 94 & $3,30 \%$ & $13,90 \%$ \\
\hline $\begin{array}{l}\text { Forms and methods for working with families and relatives of people } \\
\text { with disabilities }\end{array}$ & 93 & $3,30 \%$ & $14,00 \%$ \\
\hline Institutional roles and inter-sector relationships & 78 & $2,80 \%$ & $11,60 \%$ \\
\hline Social work and helping behavior & 77 & $2,70 \%$ & $11,50 \%$ \\
\hline Total & 2830 & $100,00 \%$ & $421,80 \%$ \\
\hline
\end{tabular}

The results show that at the first plaale with $55,1 \%$ was identified the topic of training methods for child victims of violence and their families. Secondly, the topic "Methods for case management of child at risk" $38,0 \%$, third - "Methods for early diagnosis of risk of child abandonment and prevention of abandonment" $37,7 \%$. On the fourth place is "Foster care - alternative form for raising children in family environment process and specifics"- 36,4\% ", and fifth - „Working with children - victims of trafficking and trafficking and their families"- $34,4 \%$. The themes of all five of the first upgrading trainings are highly specialized, generating constant dynamics in terms of regulation and communication with the client.

In the questionnaire, a question was asked as to what supervision the employees of the Child Protection Department need. Respondents were offered 11 responses. The aim was to gather information on the need and to identify the need for the type and reasons for conducting supervision in the near future. This would make it possible for the agency, and in particular the child protection teams, to better plan and organize the supervisions. The responses received cover topics from 11 different areas, most of which were not repeated and only concern the individual interviewee. After the analysis of the results, however, several types of supervision were highlighted, for which the respondents feel that they need to change from the current way or plan to carry out. The results are presented in Table 19.

Table 19. Supervision

\begin{tabular}{|l|c|c|c|}
\hline \multirow{2}{*}{ The supervision is needed } & \multicolumn{2}{c|}{ Answers } & \multirow{2}{*}{$\begin{array}{c}\text { Cumulative } \\
\text { percent }\end{array}$} \\
\cline { 2 - 4 } & Number & Percent & \\
\hline to overcome occupational stress and the "burn out" syndrome is social work & 306 & 19,57 & $40,20 \%$ \\
\hline to understand your skills and weaknesses & 250 & 15,57 & $32,90 \%$ \\
\hline to comment on the practice of different methods of social work & 220 & 14,07 & $28,90 \%$ \\
\hline group, within the organization & 207 & 13,24 & $27,20 \%$ \\
\hline
\end{tabular}


IJAEDU- International E-Journal of Advances in Education, Vol. III, Issue 9, December 2017

\begin{tabular}{|l|c|c|c|}
\hline individual & 159 & 10,17 & $20,90 \%$ \\
\hline to learn to make clear assessments of your work with clients / colleagues & 132 & 8,44 & $17,30 \%$ \\
\hline multiple, multidisciplined environment & 125 & 7,99 & $16,40 \%$ \\
\hline to explore your interventions & 76 & 4,89 & $10,00 \%$ \\
\hline to reflect on your social work & 62 & 3,96 & $8,10 \%$ \\
\hline to discuss ethical issues & 27 & 1,73 & $3,50 \%$ \\
\hline Total & & & $205,40 \%$ \\
\hline
\end{tabular}

The results show that, first of all, $19,57 \%$ identified the need for supervision to overcome occupational stress and the professional "burn out" syndrome. Secondly, with $15,57 \%$, there is a need for supervision to social workers to understand their skills and strengths and weaknesses. Third, by $14,07 \%$ supervision is needed to comment on the practice of different social methods. The goals of all three are highly specialized, generating constant dynamics in terms of client communication, specialized institutions and administrative work.

\section{CONCLUSION}

The survey shows that the employees of the two departments Child Protection and People with Disabilities and Social Services in the Social Assistance Directorates are actively involved in trainings and seminars and have attitudes to increase their professional qualifications organized by the Social Assistance Agency in order to increase professional experience and knowledge, to exchange experience and good practices between colleagues and departments. This is particularly important for social workers who have a professional experience of less than two years and who, for one reason or another, have not been inducluded in introductory training, as well as in places where due to a shortage of experts in departments workloads, number of cases and many different obligations increase Terziev, 2017b, pp. 1087-1106; Terziev, 2017c, pp. 1107-1125; Terziev. V. pp. 1400-1410; Terziev, 2017d, pp.1318-1329; Terziev, 2017e, pp. 923-935; Terziev, 2017f, pp. 933-939; Terziev, Arabska, 2017c, pp. 1109-1124, Terziev, Arabska, 2017d, pp.1089-1100, Terziev, Arabska, 2017e, pp. 1101-1112; Terziev, Arabska, 2017f, pp. 1113-1126; Terziev, 2017g; Terziev, Arabska, 2017g, pp. 1090-1108; Terziev, Arabska, 2017h, pp. 1466-1476; Terziev, Arabska, 2017i, pp.1458-1470; Terziev, Arabska, 2017j, pp. 925-939; Terziev, Georgiev, 2017a, pp. 94-101; Terziev, Georgiev, pp. 1418-1437; Terziev, 2017h; Terziev, Dimitrov, 2016, pp. 205-234; Terziev, Georgiev, 2017b, pp. 61-70; Terziev, Dimitrova, 2017a, pp.757-797; Terziev, Dimitrova, 2017b; Terziev, Dimitrova, 2017c, Terziev, 2017i; Terziev, 2016g, pp. 84-90; Terziev, 2017j, pp. 55-78).

Changes in the legal framework lead to the attitude of rapid and adequate organizational measures for conducting advanced trainings to update and expand knowledge in areas covered by changes. This is a problem that directly affects the daily work of the social workers. Providing timely and adequate information on these changes, organizing timely training as well as variants of ready-made models of internal regulations will save time for social workers, will help to unify the internal regulations of the departments and, last but not least, would help to generate a good working climate in the departments and hence the agency as a whole.

Employees of the Child Protection and Disability and Social Services Departments at the Social Assistance Directorate state that they need training and qualification for various professional problems and express their need for exchange of professional experience and good practices. It would be a good practice to organize roundtables, discussion forums, meetings, etc., and when necessary to discuss and solve current problems of social workers in different regions and locations, a preferred form for further qualification. On the basis of the results of the already identified trainings, a training plan could be drawn up for the years in the near future. Pre-planning will allow for greater efficiency in organizing trainings [71-95] (Terziev, 2017j, pp. 55-78; Terziev, 2017k, pp. 78-93, Terziev, Georgiev, 2017c, pp. 24-31; Terziev, Arabska. 2017k; Terziev, Arabska, 2017l, pp. 41-46; Terziev, 2017l, pp. 9-34; Terziev, Banabakova, Dimitrova, 2017a, pp. 52-81; Terziev, Banabakova, Dimitrova, 2017b, pp. 82-119; Terziev, Nichev, Arabska, 2017, pp. 322-375; Terziev, 2017m, p. 254; Terziev, 2017n, p.255; Terziev, Arabska, 2017m, pp. 54-95; Terziev, 2017o, pp. 6-12; Terziev, 2017p, pp.13-18; Terziev, Dimitrova, 2017d, pp. 825-879; Terziev, Arabska, 2017n, pp. 487-494; Terziev. Arabska, 2017o, pp.493-503; Terziev, 2017q, pp. 338-351; Terziev, Georgiev, 2017d, pp. 37-39; Kanev, Terziev, 2017, pp. 595-606; Terziev, Nichev, 2017a, pp. 556-574; Terziev, Nichev, 2017b, pp. 541-555, 
Terziev, Nichev, 2017c, pp.531-540; Terziev, 2017r, pp. 654-660; Terziev, 2017s, pp. 641-653).

\section{REFERENCE LIST}

Terziev, V., (2013) Vazdeystvie na politikite na pazara na truda za osiguryavane na zaetost“, „Dema pres Ruse“.

Terziev, V. (2016a). Competence-based training in public employment services, Tenth International Scientific Conference "The Power of Knowledge", Knowledge International Journal Scientific papers Vol. 14.1.

Terziev, V., Dimitrova, \& S., Arabska, E. (2015). Razrabotvane na kompetentsii, pregled na potentsiala na sluzhitelite i opredelyane potrebnostite ot vavezhdashto i poddarzhashto obuchenie v publichnite sluzhbi za zaetost. Natsionalna konferentsiya s mezhdunarodno uchastie „Obrazovatelni tehnologii 2015“, Izvestiya na Sayuza na uchenite - Sliven,.

Terziev, V. (2009). Intercompany training as a technology for company management staff development. Proceedings of the International Conference on Manufacturing Systems ICMaS, Vol.4.

Terziev, V., Dimitrova, S. (2014). The internal training as a process of continuous training, Mezhdunarodnaya nauchno-prakticheskaya konferentsiya, „Innovatsionnayy vektor razvitiya nauki”, Ufa, Rossiya.

Terziev, V. (2017a). Model of methodology for determining the needs of continuing vocational training of social work specialists providing social services. Evraziyskiy soyuz uchenayh (ESU), Ezhemesyachnayy nauchnayy zhurnal № 1(34) / 2017, part 2.

Terziev, V. Social and economic policies in a period of active transformations in Bulgaria, Book of Abstracts: First International Scientific Conference „Sustainability Challenges in Modern Organizations Knowledge \& Innovation in Management \& Operation“.

Terziev, V., S. Stanchev, Development of active social policies in Bulgaria, Book of Abstracts: First International Scientific Conference „Sustainability Challenges in Modern Organizations - Knowledge \& Innovation in Management \& Operation“.

Terziev. V., E. Arabska, (2016a) State of the labor market in Bulgaria, VII international scientific and applicative conference KNOWLEDGE WITHOUT BORDERS, 8-10 April 2016, Bansko, Bulgaria. International Journal Scientific Papers Vol. 12.2,.

Terziev. V., E. Arabska, (2016b) Functional Public Service in Perspectives 2020, VII international scientific and applicative conference KNOWLEDGE WITHOUT BORDERS, International Journal Scientific Papers Vol. 12.2,

Terziev. V., E. Arabska, \& S. Filipov, \& S. Stanchev, (2016a) Indicators for Monitoring of the Active Policy on the Labor Market in Bulgaria. The international trade XI scientific conference "Innovations in tehnologiyana and obrazovanii" Kuzbasskiy gosudarstvennыy; Technical University them. T.F. 18-19 March 2016 Часть 4.

Terziev. V., E. Arabska, S. Filipov, S. Stanchev, (2016b) Implementation of programs and measures of active labor market policy in Bulgaria. The international trade XI scientific conference "Innovations in tehnologiyana and obrazovanii" Kuzbasskiy gosudarstvennыy; Technical University them. T.F. 18-19 March 2016 Часть 4,.

Terziev. V., E. Arabska, \& S. Filipov, \& S. Stanchev, (2016c) Policies for Building a Functioning Labor Market in Bulgaria and Impact on Vulnerable Groups. The international trade XI scientific conference "Innovations in tehnologiyana and obrazovanii" Kuzbasskiy gosudarstvennыy; Technical University them. T.F. 18-19 March 2016 г. Часть 4.

Terziev. V., E. Arabska, \& S. Filipov, \& S. Stanchev, (2016d) Challenges to the Development of the Labor Market and the Role of the Public Employment Services. The international trade XI scientific conference "Innovations in tehnologiyana and obrazovanii" Kuzbasskiy gosudarstvennыy; Technical University them. T.F., 18-19 March 2016 Часть 4. 
IJAEDU- International E-Journal of Advances in Education, Vol. III, Issue 9, December 2017

Terziev. V., E. Arabska, (2016c) Impact of Active Policy and Employment Intermediation Services in Bulgaria. Fourteenth Youth Scientific Practice Conference, Federation of Scientific and Technical Unions, Collection of Reports.

Terziev. V., E. Arabska, (2016d) Main profiles of unemployed persons in Bulgaria. Fourteenth Youth Scientific and Practical Conference, Federation of Scientific and Technical Unions, Collection of Reports.

Terziev. V., E. Arabska, (2016e) Dynamics in vulnerable groups on the labor market in Bulgaria. Fourteenth Youth Scientific and Practical Conference, Federation of Scientific and Technical Unions, Collection Reports.

Terziev. V., E. Arabska, (2016f) Labor Market Trends and Labor Force Survey in Bulgaria. Fourteenth Youth Scientific and Practical Conference, Federation of Scientific and Technical Unions, Collection of Reports.

Terziev. V., E. Stoyanov, (2016a) Social program as a product of social programming. Laws and trends in the development of science in modern society. Collection of articles of the International Scientific and Practical Conference, SIC AERTHERA,.

Terziev. V., E. Stoyanov, (2016b) Social activity of the human resource - the basis of effective social policy. Problems, perspectives and directions of innovative development of science. Collection of articles of the International Scientific and Practical Conference, SIC AERTHERA.

Terziev. V., E. Stoyanov, (2016c) Strategic advantages of the active social program. Problems, perspectives and directions of innovative development of science. Collection of articles of the International Scientific and Practical Conference SIC AERTHERA.

Terziev. V., E. Stoyanov, (2016d) Social efficiency as a measure of activity in society. International Journal of Innovation Science, N 3/2016, AERTERNA.

Terziev. V., N. Bencheva, T. Stoeva, E. Arabska, (2016) Social enterprises in Bulgaria. International scientific-practical conference „Prospects for the development of science and education”, Scientific journal "Economics and Finance" Plovdiv.

Terziev. V., N. Bencheva, E. Arabska, (2016) Implications on the development of social economy in Bulgaria, International Scientific and Practical Conference „Prospects for the Development of Science and Education", Journal of Economics and Finance Plovdiv.

Terziev. V., N. Bencheva, M. Tepavicharova, E. Arabska, (2016) Encouragement of social entrepreneurship in Bulgaria. International scientific-practical conference „Prospects for the development of science and education”, Scientific journal „Economics and Finance”.

Terziev. V., E. Arabska, (2016g) Impact of social enterprises, International Scientific Conference. Statement on the timing of the selection of products, 6-7 oktomvri, 2016. National University „Vasil Levski", Faculty of Artillery, Air Defense and KIS - Sh. Shumen, Military Technical Academy, Bukuresh, Romania, National University for selection.

Terziev. V., E. Arabska, (2016h) Social enterprises and social entrepreuners. - International scientific conference. Statement on the timing of the selection of products, 6-7 oktomvri, 2016. National Voyenen University „Vasil Levski”, Faculty of Artillery, Air Defense and the CIS - Shumen, Military Technical Academy, Bukuresh, Rumnia, National University, selected.

Terziev. V., Arabska, E. (2016i) Social entrepreneurship in Europe, International Scientific Conference. Statement on the timing of the selection of products, 6-7 oktomvri, 2016. Natsionalen Voenen University „Vasil Levski”, Faculty of Artillery, Air Defense and the CIS - Shumen, Military Technical Academy, Bukureş, Rumnia, National University, selected.

Terziev. V., (2016c) Development on the labor market in Bulgaria and the impact on policy monitoring in the region on unemployment and unemployment, Write-off of „Economics 21", CA „D.A. Tsenov“Svishtov, Godina VI, book 2.

Terziev. V., P. Dimitrova, (2014a) Development of the social support system in Bulgaria, Collection of articles of the International Scientific and Practical Conference „Actual problems of modern science“, Aeterna (Ufa).

Terziev. V., P. Dimitrova, (2014b) Development of the structure of the social support system in Bulgaria, Collection of articles of the International Scientific and Practical Conference „Actual problems of 
modern science“, Aeterna (Ufa) 2014, ISBN: 978-5-906769-47-3, p. 294-307.

Terziev. V., E. Arabska, (2016j) Social Policy Development and Implementation: Municipal level perspectives, HASSACC 2016 - Human and Social Sciences at the Common Conference.

Terziev. V., (2016d) Social policies on labor market as theory and practice in Bulgaria, International scientific conference „Economic well-being through spodelane for knowledge“, is dedicated to the 80th year from the foundation of the academy „D. A. Tsenov“- Svishtov, Volume 1.

Terziev. V., E. Stoyanov, E. Arabska, (2016) Monitoring of the active social policies on labor market: the case of Bulgaria. Business Economics, ISSN 0007-666X, Palgrave Macmillan Ltd., No. 4 (51) / 2016.

Dimitrovski. R., V. Terziev, S. Saliu, L. Pushova, (2016) Managing the problem of unemployment in the republic of Macedonia, Tenth International Scientific Conference THE POWER OF KNOWLEDGE, Agia Triada, Republic of Greece. Knowledge International Journal Scientific papers Vol. 14.3.

Terziev. V., Development of labor market in Bulgaria and impact of policies on employment and unemployment. Stopanska Academy „D. A. Tsenov“- Svishtov, sp. „Economics 21“.

Terziev. V., E. Arabska, R. Dimitrovski, L. Pushova, (2016) Challenges to social entrepreneurship development in Bulgaria, Conference Bansko 2016. Eleventh International Conference: KNOWLEDGE CAPITAL OF THE FUTURE, KNOWLEDGE International Journal Scientific Papers.

Terziev. V., (2016e) Social Entrepreneurship in Bulgaria and Europe, International Scientific Conference, International Scientific Conference on Social Entrepreneurship - Agricultural University of Plovdiv).

Terziev. V., E. Arabska, (2016k) Needs and Challenges of Social Entrepreneurs, International Scientific Conference.

Terziev. V., (2016f) Impacts of active social programs on labor market. The X International Academic Congress "Contrmporary Science and Education in Americas, Africa and Eurasia”.

Terziev. V., (2017a) Management of the effective social programming or the controlled beginning of the good future, European Review of Economic Hitory, №1 (21) 2017.

Terziev. V., E. Arabska, (2017a) Providing business support to social entrepreneurs, Children \& Schools, Issue 4 (2), (October), Volume 39. Oxford University Press.

Terziev. V., N. Nichev, S. Simeonov, Historical development and characteristics of pension systems, Review of Finance, Issue 6 (2), (October), Volume 21. Oxford Universty.

Terziev. V., E. Arabska, (2017b) Examining social enterprise business advisors job profiles and qualifications, Review of Finance, Issue 6 (2), (October), Volume 21. Oxford University Press.

Terziev. V., (2017b) Development of the social assistance system's structure in Bulgaria, Past \& Present, Issue 1 (2), (November), Volume 237. Oxford University Press.

Terziev. V., (2017c) Development of the social assistance system in Bulgaria, Past \& Present, Issue 1 (2), (November), Volume 237. Oxford University Press, 2017.

Terziev. V., Impact of the labor market policies for ensuring employment, Journal of Economic Geography, Issue 6 (2), (November), Volume 17.

Terziev. V., (2017d) Building a model of social and pshychological adaptation, The Journal of Medicine and Philosophy, Issue 6 (2), (December), Volume 42. Oxford University Press.

Terziev. V., (2017e) Factors affecting the process of social adaptation, European Journal of International Law, №1(28) 2017.

Terziev. V., (2017f) Importance of human resources to social development, Oxford Journal of Legal studies, Issue 4 (2), Volume 37. Oxford University Press.

Terziev. V., Arabska. E., (2017c) Chalenges to social entrepreneurship development in Bulgaria, Social Problems, Social Problems, Issue 4 (2), (November), Volume 64. Oxford University Press.

Terziev. V., Arabska. E., (2017d) Development of the concept of social entrepreneurshipo in Europe, The British Journal for the Philosophy of Science, Issue 4 (2), (December), Volume 68. Oxford University Press.

Terziev. V., Arabska. E., (2017e) Social entrepreneurship social values and social impact, The British Journal for the Philosophy of Science, Issue 4 (2), (December), Volume 68. Oxford University Press. 
Terziev. V., Arabska. E., (2017f) Social enterprises - a sustainable business model, The British Journal for the Philosophy of Science, Issue 4 (2), (December), Volume 68. Oxford University Press.

Terziev. V., (2017g) Improvement in the work of the institutions on labor market through a process model, European Sociological Review, №1(33) 2017.

Terziev. V., Arabska. E., (2017g) Social policies on labor market as the theory and practice in Bulgaria, Social Problems, Social Problems, Issue 4 (2), (November), Volume 64. Oxford University Press.

Terziev. V., Arabska. E., (2017h) Skills requirements from advisors so as to provide effective support to social enterprises, Family Practice, №1(34) 2017.

Terziev. V., Arabska. E., (2017i) Social entrepreneurship in Bulgaria and Europe, Health Education Research, №1(32) 2017.

Terziev. V., Arabska. E., (2017j) Needs and challenges of social entrepreneurs, Literature and Theology, Issue 4 (2), (December), Volume 31. Oxford University Press.

Terziev. V., M. Georgiev, (2017a) Active Social Programs Development in Bulgaria: Contemporary Challenges and Social Management Instruments, International Journal of Humanities and Social Science Invention, Vol.6, Issue 1.

Terziev. V., Georgiev, M. The active model of a social programme and its strategic advantage. Medical Teacher, №7-8(39).

Terziev. V., (2017h) Development of the social support system in Bulgaria, Economic theory, UNIVERSUM: Economic and Jurisprudence, No.1 (34).

Terziev. V., P. Dimitrov, (2016) Models for the methodical course for the determination of the need for professional training in a specialist in social services, providing social services, International Scientific Conference, 29 September 2016, Plovdiv, Bulgaria, International scientific conference on social entrepreneurship-Agraren University Plovdiv.

Terziev. V., M. Georgiev, (2017b) Social Enterprise and Their Influence International Scientific Conference, 29 September 2016, Plovdiv, Bulgaria, International Scientific Conference on Social EntrepreneurshipAgraren University Plovdiv.

Terziev, V., P. Dimitrova, (2017a) Model of methodology for determining the needs of continuing vocational training of social work specialists providing social services, American Journal of Education, No.4 (2), (August). Volume 123. The University of Chicago Press.

Terziev. V., P. Dimitrova, (2017b) Social policy as a tool for social development, Universum, Economics and jurisprudence: electron. Scientific. Journal. 2017, No.2 (35).

Terziev. V., P. Dimitrova, (2017c) Continuing vocational training in Bulgaria, Universum, Economics and jurisprudence: electron. Scientific. Journal. 2017, No.2 (35).

Terziev. Venelin, (2017i) Social Support System in Bulgaria: Stages of Development and Development, Universum, Economics and Jurisprudence: electronic. Scientific. Journal. 2017, No. 2 (35).

Terziev. V., (2016g) Human Resource Management Systems for Social Activities, XXXII International Scientific and Practical Conference, Eurasian Union of Scientists (ECU), Monthly Scientific Journal No.12 (33) / 2016 Part 1.

Terziev. V., (2017j) Model of methodology for determining the needs of continuing social work, the Eurasian Union of Scientists (ESU), Monthly Scientific Journal No. 1 (34) / 2017, 2 Part.

Terziev. V., (2017k) Research identification and monitoring of the needs of the occupational training of social activities experts, Eurasian Union of Scientists (ECU), Monthly Scientific Journal No. 1 (34) / 2017, 2 Part.

Terziev. V., M. Georgiev, (2017c) Impact of the labor market policies for ensuring employment, Proceedings of Academics World $57^{\text {th }}$ International Conference, Paris, France.

Terziev. V., Arabska. E., (2017k) Social enterprises - a sustainable business model, IOSRD (International Organization of Scientific Research and Development) 14th International Conference on Developments in science, Management and Engineering.

Terziev, V., E. Arabska, (2017l) Social Entrepreneurship in Terms of Social Values and Social Impact, International Journal of Research in Management, Economics and Commerce. 
Terziev, V., (2017l) Research on the Status of Social Entrepreneurship in Bulgaria: a Presentation of a Project Report's Primary Data, Journal of Innovations and Sustainability Volume 3, Number 1.

Terziev, V., V. Banabakova, P. Dimitrova, (2017a) Research, Identification and Monitoring of the Needs of Occupational Training of Social Activities Experts, Collection of Reports of the Annual University Scientific Conference Volume 6 Scientific Direction „Social, Economic and Social Sciences“.

Terziev, V., V. Banabakova, P. Dimitrova, (2017b) Model of Methodology for Determining the Needs of Continuing Vocational Training of Social Work Specialists Providing Social Services, Compilation of a report from the University University Scientific Conference Volume 6 Scientific direction „Sotsialni, Stopanski and Science".

Terziev. V., Nichev N., Arabska E., (2017) Analysis on the development of social development in Bulgaria, Svrmenenni trends in aviation education, a compilation of the report on the Scientific Conference on 18-19 May 2017.

Terziev, V., (2017m) Social Policy as Theory and Practice in Bulgaria, 3rd Central and Eastern European LUMEN International Scientific Conference New Approaches in Social and Humanistic Sciences 8-10 June 2017 | Chisinau, Republic of Moldova.

Terziev, V., (2017n) Social Entrepreneurship as an Opportunity to Model an Active Social Program, $3^{\text {rd }}$ Central and Eastern European LUMEN International Scientific Conference New Approaches in Social and Humanistic Sciences.

Terziev, V., E. Arabska, $(2017 \mathrm{~m})$ Social entrepreneurship development in Bulgaria, management and education, economics, finance accounting, University "Prof. Dr Assen Zlatarov ", Vol. XIII (1) 2017.

Terziev, V., (20170) Social entrepreneurship as an opportunity to model an active social program, Topical issues of contemporary science: Collection of scientific articles. - C.E.I.M.

Terziev, V., (2017p) Social policy as theory and practice in Bulgaria, Topical issues of contemporary science: Collection of scientific articles. - C.E.I.M.

Terziev, V., P. Dimitrova, (2017d) Research, identification and monitoring of the needs of occupational training of social activities experts, American Journal of Education, No.4 (2), (August). Volume 123. The University of Chicago Press.

Terziev, V., E. Arabska, (2017n) Analysis of the process of social entrepreneurship in Bulgaria, XIV International Scientific Conference MANAGEMENT AND ENGINEERING '17.

Terziev, V. E. Arabska, (20170) Social entrepreneurship development in Bulgaria, XIV International Scientific Conference MANAGEMENT AND ENGINEERING '17, DAYS OF SCIENCE AT TU-SOFIA.

Terziev, V., (2017q) The system of social services in Bulgaria and the process of deinstitutionalisation of children, Proceedings of the VII International Academic Congress „Fundamental and Applied Studies in EU and CIS Countries" (United Kingdom, Cambridge, England, 26-28 February 2017). Volume VII. Cambridge University Press.

Terziev, V., M. Georgiev, (2017d) Importance of human resources to social development, International Journal of Management and Applied Science, Volume-3, Issue-4.

Kanev, D., V. Terziev, (2017) Behavi oral economi cs: development, condi ti on and perspecti ves, Proceedings of SOCIOINT 2017- $4^{\text {th }}$ International Conference on Education, Social Sciences and Humanities 10-12 July 2017- Dubai, UAE.

Terziev, V., N. Nichev, (2017a) Research, identification and monitoring of the needs of occupational training of social activities experts, Proceedings of SOCIOINT 2017- $4^{\text {th }}$ International Conference on Education, Social Sciences and Humanities 10-12 July.

Terziev, V., N. Nichev, (2017b) Model of methodology for determining the needs of continuing vocational training of social work specialists providing social services, Proceedings of SOCIOINT 2017- $4^{\text {th }}$ International Conference on Education, Social Sciences and Humanities 10-12 July 2017- Dubai, UAE.

Terziev, V., N. Nichev, (2017c) Strategic framework for social entrepreneurship development in Bulgaria, Proceedings of SOCIOINT 2017- $4^{\text {th }}$ International Conference on Education, Social Sciences and Humanities 10-12 July 2017- Dubai, UAE.

Terziev, V., (2017r) Social entrepreneurship as an opportunity to model an active social program, 
Proceedings of SOCIOINT 2017- $4^{\text {th }}$ International Conference on Education, Social Sciences and Humanities 10-12 July 2017- Dubai, UAE.

Terziev, V., (2017s) The needs of continuing vocational training of social work specialists providing social services, Proceedings of SOCIOINT 2017- $4^{\text {th }}$ International Conference on Education, Social Sciences and Humanities 10-12 July 2017- Dubai, UAE. 